\title{
Eelgrass Sediment Microbiome as a Nitrous Oxide Sink in Brackish Lake Akkeshi, Japan
}

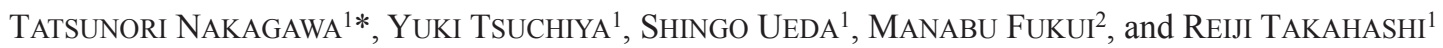 \\ ${ }^{1}$ College of Bioresource Sciences, Nihon University, 1866 Kameino, Fujisawa, 252-0880, Japan; and ${ }^{2}$ Institute of Low Temperature \\ Science, Hokkaido University, Kita-19, Nishi-8, Kita-ku, Sapporo, 060-0819, Japan
}

(Received July 16, 2018-Accepted October 22, 2018—Published online December 1, 2018)

Nitrous oxide $\left(\mathrm{N}_{2} \mathrm{O}\right)$ is a powerful greenhouse gas; however, limited information is currently available on the microbiomes involved in its sink and source in seagrass meadow sediments. Using laboratory incubations, a quantitative PCR (qPCR) analysis of $\mathrm{N}_{2} \mathrm{O}$ reductase (nos $\mathrm{Z}$ ) and ammonia monooxygenase subunit $\mathrm{A}(\mathrm{amoA})$ genes, and a metagenome analysis based on the nos $\mathrm{Z}$ gene, we investigated the abundance of $\mathrm{N}_{2} \mathrm{O}$-reducing microorganisms and ammonia-oxidizing prokaryotes as well as the community compositions of $\mathrm{N}_{2} \mathrm{O}$-reducing microorganisms in in situ and cultivated sediments in the non-eelgrass and eelgrass zones of Lake Akkeshi, Japan. Laboratory incubations showed that $\mathrm{N}_{2} \mathrm{O}$ was reduced by eelgrass sediments and emitted by non-eelgrass sediments. qPCR analyses revealed that the abundance of nos $Z$ gene clade II in both sediments before and after the incubation as higher in the eelgrass zone than in the non-eelgrass zone. In contrast, the abundance of ammonia-oxidizing archaeal amo $A$ genes increased after incubations in the non-eelgrass zone only. Metagenome analyses of nos $Z$ genes revealed that the lineages Dechloromonas-Magnetospirillum-Thiocapsa and Bacteroidetes (Flavobacteriia) within nosZ gene clade II were the main populations in the $\mathrm{N}_{2} \mathrm{O}$-reducing microbiome in the in situ sediments of eelgrass zones. Sulfur-oxidizing Gammaproteobacteria within nosZ gene clade II dominated in the lineage Dechloromonas-Magnetospirillum-Thiocapsa. Alphaproteobacteria within nosZ gene clade I were predominant in both zones. The proportions of Epsilonproteobacteria within nos $Z$ gene clade II increased after incubations in the eelgrass zone microcosm supplemented with $\mathrm{N}_{2} \mathrm{O}$ only. Collectively, these results suggest that the $\mathrm{N}_{2} \mathrm{O}$-reducing microbiome in eelgrass meadows is largely responsible for coastal $\mathrm{N}_{2} \mathrm{O}$ mitigation.

Key words: nitrous oxide-reducing microbiome, nosZ, amoA, eelgrass sediments, sulfur-oxidizing Gammaproteobacteria, Flavobacteriia

Nitrous oxide $\left(\mathrm{N}_{2} \mathrm{O}\right)$ is a powerful, long-lived greenhouse gas (45) and causes the depletion of the stratospheric ozone layer (54). In natural ecosystems, $\mathrm{N}_{2} \mathrm{O}$ is predominantly produced through the microbial processes of denitrification, nitrification, and nitrifier-denitrification (27, 72, 83). Among these mechanisms, coastal and estuarial $\mathrm{N}_{2} \mathrm{O}$ sources are assumed to be mainly due to sediment denitrification $(46,47)$. $\mathrm{N}_{2} \mathrm{O}$ emissions from an open ocean have recently been attributed to nitrification by ammonia-oxidizing archaea (AOA) $(40,61)$. However, limited information is currently available on the relationship between $\mathrm{N}_{2} \mathrm{O}$ emissions and nitrifiers in seagrass sediments. Moreover, the consumption of $\mathrm{N}_{2} \mathrm{O}$ was previously reported in sediments of eelgrass (Zostera marina) meadows (47). Considerable sediment $\mathrm{N}_{2} \mathrm{O}$ uptake has recently been reported in pristine shallow coastal ecosystems $(20,41)$, and rapid $\mathrm{N}_{2} \mathrm{O}$ reduction has been discovered in the suboxic ocean (4).

Denitrification is the sequential reaction of nitrate to the gaseous products $\mathrm{N}_{2} \mathrm{O}$ and/or nitrogen gas $\left(\mathrm{N}_{2}\right)$ via nitrite $\left(\mathrm{NO}_{2}{ }^{-}\right)$and nitric oxide $(\mathrm{NO})\left(\mathrm{NO}_{3}{ }^{-} \rightarrow \mathrm{NO}_{2}{ }^{-} \rightarrow \mathrm{NO} \rightarrow \mathrm{N}_{2} \mathrm{O} \rightarrow \mathrm{N}_{2}\right.$ ). Z-type $\mathrm{N}_{2} \mathrm{O}$ reductase (NosZ) is a key enzyme that catalyzes the reduction of $\mathrm{N}_{2} \mathrm{O}$ to $\mathrm{N}_{2}$ during denitrification under sufficiently low molecular oxygen conditions $(11,34)$. Therefore, the step of $\mathrm{N}_{2} \mathrm{O}$ reduction by the enzyme NosZ is a major process that influences $\mathrm{N}_{2} \mathrm{O}$ flux to the atmosphere $(72,84)$. Many prokaryotes, including more than 60 genera of bacteria, have the ability to denitrify heterotrophically (65). Autotrophic

\footnotetext{
* Corresponding author. E-mail: nakatats@brs.nihon-u.ac.jp;
} Tel: +81-466-84-3359; Fax: +81-466-84-3359. denitrifiers are also able to utilize nitrate $\left(\mathrm{NO}_{3}^{-}\right)$and/or $\mathrm{NO}_{2}{ }^{-}$ as the electron acceptor and reduce $\mathrm{N}_{2} \mathrm{O}$ to $\mathrm{N}_{2}$ using the enzyme NosZ (64). Some autotrophic denitrifying sulfur oxidizers have the nos $Z$ gene on the whole genome, such as Thiobacillus denitrificans and Sulfuritalea hydrogenivorans within Betaproteobacteria (5,33), Sedimenticola thiotaurini within Gammaproteobacteria (19), and Sulfurimonas denitrificans within Epsilonproteobacteria (67). Chemolithoautotrophic denitrifiers within Gammaproteobacteria and Epsilonproteobacteria play an important role in the nitrogen cycle in the oxygen minimum zone in the ocean (37). nos $Z$ genes have recently been classified into two phylogenetically distinct NosZ clades: the first encodes typical NosZ proteins, now designated as nosZ gene clade I, while the other encodes atypical Nos $Z$ proteins, now designated as $n o s Z$ gene clade II, including the denitrifying members of Gammaproteobacteria, Epsilonproteobacteria, and the phylum Bacteroidetes as well as the non-denitrifying microorganisms of genera such as Anaeromyxobacter, Dyadobacter, and Ignavibacterium $(29,60)$. PCR and metagenomic analyses based on the nos $Z$ gene revealed that nos $Z$ gene clade II is more abundant and widespread than nos $Z$ gene clade I in several environments such as soil $(29,30,43,51)$, wastewater treatment plants (29), marine water (70), and marine sediments $(3,56,79)$. Furthermore, previous studies demonstrated that non-denitrifying $\mathrm{N}_{2} \mathrm{O}$-reducing bacteria within nos $\mathrm{Z}$ gene clade II played an important role in the consumption of $\mathrm{N}_{2} \mathrm{O}$ within soil $(14,52,81)$. However, limited information is currently available on the distribution and community structure of microbiomes with the capacity to reduce $\mathrm{N}_{2} \mathrm{O}$ in eelgrass sediments. 
Seagrass meadows provide the stabilization of sediment, a habitat for ecologically diverse and productive ecosystems that reduce the exposure of humans, fishes, and invertebrates to bacterial pathogens in coastal environments $(16,38)$. Sediments inhabited by seagrasses are generally anoxic due to sulfide produced by sulfate-reducing bacteria that utilize sulfate as an electron acceptor for the mineralization of organic matter accumulated by seagrasses (9). Molecular ecological studies based on $16 \mathrm{~S}$ rDNA previously revealed the predominance of sulfur-oxidizing bacteria(SOB) within Gammaproteobacteria and/or Epsilonproteobacteria together with sulfate-reducing bacteria in seagrass sediments $(10,12,17,73)$. Some SOB within Gammaproteobacteria and/or Epsilonproteobacteria possess the nos $Z$ gene $(22,28)$. Since high denitrification rates have been reported within the surface of seagrass sediments (8), we hypothesized that SOB possessing the nos $Z$ gene may be responsible for the $\mathrm{N}_{2} \mathrm{O}$ sink in seagrass sediments alongside their role in sulfide detoxification for seagrasses growing in sulfidic sediments $(24,75)$.

To test this hypothesis, we characterized the microbiomes responsible for $\mathrm{N}_{2} \mathrm{O}$ reduction in eelgrass meadow sediments using the high-throughput sequencing of the nos $Z$ gene and quantitative PCR (qPCR) analyses of nos $Z$ and ammonia monooxygenase subunit A ( $a m o A)$ genes. Since PCR primers for $n o s Z$ gene clade II have limitations for investigating the diversities of the genera Anaeromyxobacter and Sulfurimonas and the phylum Bacteroidetes due to PCR bias (29), we examined the community structures of the $\mathrm{N}_{2} \mathrm{O}$-reducing microbiome using shotgun metagenomic analyses based on nos $Z$ gene clades I and II. The community structures of microbiomes in sediments were compared between non-eelgrass and eelgrass zones. Laboratory incubations of sediment microcosms were also conducted for sediments from both zones to elucidate the relationship between the community structures of the $\mathrm{N}_{2} \mathrm{O}$ reducing microbiome and $\mathrm{N}_{2} \mathrm{O}$ sink. Since few studies have investigated the influence of nitrogen fertilizers on the coastal areas, such as the sharp increase in $\left(\mathrm{NH}_{4}\right)_{2} \mathrm{SO}_{4}$ due to increased precipitation, we examined the influence of ammonium on nitrification and $\mathrm{N}_{2} \mathrm{O}$ production in non-eelgrass and eelgrass zone sediments.

\section{Materials and Methods}

\section{Study area and sampling}

The study area was Lake Akkeshi, a brackish lake located in Hokkaido, Japan. Most of the lake $\left(31.8 \mathrm{~km}^{2}\right)$ is covered with the eelgrass Zostera marina (80). Sediment core samples were obtained at two different positions, a non-eelgrass zone $\left(43^{\circ} 03^{\prime} 54^{\prime \prime} \mathrm{N}\right.$, $\left.144^{\circ} 51^{\prime} 36^{\prime \prime} \mathrm{E}\right)(n=1)$ (Fig. S1A and $\left.\mathrm{C}\right)$ and an eelgrass zone $\left(43^{\circ} 03^{\prime} 18^{\prime \prime} \mathrm{N}, 144^{\circ} 53^{\prime} 24^{\prime \prime} \mathrm{E}\right)(n=1)$ (Fig. S1B and D), by a diver using a plastic corer ( $8 \mathrm{~cm}$ in diameter and $50 \mathrm{~cm}$ in length) on 28 July, 2015. A sample of the surface water was also obtained in a $1-\mathrm{L}$ sterilized plastic bottle at the two different zones described above. The temperature, $\mathrm{pH}$, dissolved oxygen (DO), concentrations of $\mathrm{NO}_{3}{ }^{-}$and sulfate $\left(\mathrm{SO}_{4}{ }^{2-}\right)$ in surface water, and water depth in the non-eelgrass zone were $18.2^{\circ} \mathrm{C}, \mathrm{pH} 7.6, \mathrm{DO} 6.2 \mathrm{mg} \mathrm{L}^{-1}, 4.1 \mu \mathrm{M}$ and $17.3 \mathrm{mM}$ in surface water, and $0.5 \mathrm{~m}$, respectively. The eelgrass zone had a temperature of $19.6^{\circ} \mathrm{C}, \mathrm{pH}$ of 7.5 , DO of $6.5 \mathrm{mg} \mathrm{L}^{-1}, 3.5 \mu \mathrm{M}$ $\mathrm{NO}_{3}{ }^{-}, 19.3 \mathrm{mM} \mathrm{SO}_{4}{ }^{2-}$, and water depth of $1.0 \mathrm{~m}$. A $0.0-4.0-\mathrm{cm}$ layer of sediment (Fig. S1E) was sliced from the core using a stainless steel corer $(7.0 \mathrm{~cm}$ in diameter and $4.0 \mathrm{~cm}$ in length). While the color of the sediment obtained from the non-eelgrass zone was dark brown, that from the eelgrass zone was black and sulfidic (Fig. S1F and $\mathrm{G}$ ). The sediments collected were placed into sterilized $50-\mathrm{mL}$ plastic tubes. The concentrations of $\mathrm{NO}_{3}{ }^{-}$and $\mathrm{SO}_{4}{ }^{2-}$ in the pore water of sediments were $8.1 \mu \mathrm{M}$ and $20.2 \mathrm{mM}$ in the non-eelgrass zone and $5.2 \mu \mathrm{M}$ and $20.9 \mathrm{mM}$ in the eelgrass zone, respectively. Samples were transferred to the laboratory in an ice-cooled box within $3 \mathrm{~d}$. Sediments were centrifuged in the sterile $50-\mathrm{mL}$ plastic tubes $\left(5,800 \times g, 4^{\circ} \mathrm{C}, 10 \mathrm{~min}\right)$ and then mixed well after the supernatant had been discarded. Sediments for the incubation test were kept on ice until incubation experiments. Sediments for DNA extraction were stored at $-80^{\circ} \mathrm{C}$. One liter of seawater from the two different zones was filtered using Nalgene Rapid-Flow Filters (pore size, $0.2 \mu \mathrm{m}$; Thermo Fisher Scientific, Waltham, MA, USA).

\section{Cultivation of sediment microcosms and $\mathrm{N}_{2} \mathrm{O}$ analysis}

Sediment incubation experiments (three biological replicates) were performed for the non-eelgrass zone and eelgrass zone. Fiftymilliliter serum bottles (GL Sciences, Tokyo, Japan) containing $5 \mathrm{~g}$ of sediments and $15 \mathrm{~mL}$ of filter-sterilized seawater (Fig. S1F and G) were closed with black butyl rubber stoppers (Nichiden-Rika Glass, Kobe, Japan), capped with an aluminum crimp seal (GL Sciences), and then incubated at $20^{\circ} \mathrm{C}$ for $7 \mathrm{~d}$ in the dark. The bottles were shaken by hand for a few second once a day during the 7-d incubation (except on day 6 of the incubation). Three treatments were prepared for two different zones: one as a control (not amended) designated with the sample names N1 for the non-eelgrass zone and E1 for the eelgrass zone, one treated with $3.2 \mathrm{mM} \mathrm{NH}_{4} \mathrm{Cl}$ seawater ( $\mathrm{N} 2$ for the non-eelgrass zone and E2 for the eelgrass zone) to enhance the activity of ammonia oxidizers, and one spiked with $0.3 \mathrm{~mL}$ of $99.5 \%$ $\mathrm{N}_{2} \mathrm{O}$ (N3 for the non-eelgrass zone and $\mathrm{E} 3$ for the eelgrass zone) in order to confirm differences in net $\mathrm{N}_{2} \mathrm{O}$ absorption between the non-eelgrass and eelgrass zones. Each treatment was conducted in triplicate, giving a total of nine bottles in each zone. The gas in the headspace of the bottle after day 7 of the incubation was withdrawn via the closed butyl rubber stopper using a Pressure-Lok precision analytical syringe (VICI Precision Sampling, Baton Rouge, LA, USA) for the $\mathrm{N}_{2} \mathrm{O}$ analysis. $\mathrm{N}_{2} \mathrm{O}$ concentrations were measured with a gas chromatograph equipped with an electron capture detector (GC-14B; Shimadzu, Kyoto, Japan). Sediment and seawater in serum bottles after day 8 of the incubation were centrifuged in the sterile $50-\mathrm{mL}$ plastic tubes $\left(5,800 \times g, 4^{\circ} \mathrm{C}, 10 \mathrm{~min}\right)$ and then stored at $-80^{\circ} \mathrm{C}$ after the supernatant had been discarded.

\section{Nucleic acid extraction}

Each wet sediment $(\sim 0.5 \mathrm{~g}$ ) before (in situ) and after the incubation was added to a plastic tube containing lysis solutions and beads in ISOIL for the Beads Beating Kit (Nippon Gene, Toyama, Japan), mixed vigorously for $45 \mathrm{~s}$, and then incubated at $65^{\circ} \mathrm{C}$ for $1 \mathrm{~h}$. Nucleic acids were extracted according to the manufacturer's protocol, and extracted nucleic acids in $20 \mu \mathrm{L}$ of Tris-EDTA (TE) buffer were then stored at $-20^{\circ} \mathrm{C}$. Twenty-four DNA samples were extracted from the incubated sediments (N1, N2, N3, E1, E2, and E3) and in situ sediments were designated with the sample names $\mathrm{Ni}$ for the non-eelgrass zone and $\mathrm{Ei}$ for the eelgrass zone.

\section{qPCR of nosZ and amoA genes}

Regarding the quantification of $n o s Z$ and amo $A$ gene copies, each DNA solution extracted from sediments before (in situ) and after the incubation was quantified by real-time PCR in a CFX96 Real-Time System (Bio-Rad, Hercules, CA, USA) using the SYBR Premix Ex Taq (Tli RNase H Plus) kit (TaKaRa Bio, Kusatsu, Japan). Twentythree of the DNA samples were used for qPCR: duplicate DNA samples from N3 due to the loss of samples, and triplicate DNA samples from the remaining sediment samples. The following detection primer sets were used: nosZ2F and nosZ2R for nosZ gene clade I (26), modified nosZ-II-Fn (5'-CTN GGN CCN YTK CAY AC-3') and nosZ-II-Rn (5'-GCN GAR CAR AAN TCB GTR C-3') for $n o s Z$ gene clade II (29), GenAOAF and GenAOAR for the AOA amoA gene (44), and $a m o A-1 \mathrm{~F}$ and $a m o A-2 \mathrm{R}$ for the beta-proteobacterial 
ammonia-oxidizing bacteria (AOB) amoA gene (57). Standard curves were generated from a plasmid containing each of the following cloned genes: the nos $Z$ clade I gene fragment of Pseudomonas stutzeri NBRC14165 amplified with the PCR primers nosZ 1F (15) and nosZ2R for nos $Z$ gene clade I (26), the nos $Z$ clade II gene fragment of the environmental clone G3H008 amplified with the PCR primers nosZ-II-Fn and nosZ-II-Rn (Fig. S2), the AOA amoA gene fragment of Nitrosopumilus sp. NM25 amplified with the PCR primers CrenAMO_F and CrenMO_R (23), and the AOB amoA gene fragment of Nitrosomonas stercoris KYUHI-S ${ }^{\mathrm{T}}$ amplified with the PCR primers $a m o A-1 \mathrm{~F}$ and $a m o A-2 \mathrm{R}$. Each reaction was performed in a volume of $25 \mu \mathrm{L}$ containing $2 \mu \mathrm{L}$ of diluted DNA solution (one fiftieth of template DNA), $0.2 \mu \mathrm{M}$ of each primer $(1.0 \mu \mathrm{M}$ of each primer only for nos $Z$ gene clade I), and $12.5 \mu \mathrm{L}$ of SYBR Premix Ex Taq (Tli RNase H Plus). Cycling conditions were as follows: for $n o s Z$ clade I (26), an initial denaturation step at $95^{\circ} \mathrm{C}$ for $3 \mathrm{~min}$, followed by 6 cycles at $95^{\circ} \mathrm{C}$ for $15 \mathrm{~s}, 65^{\circ} \mathrm{C}$ for $30 \mathrm{~s}$, and $72^{\circ} \mathrm{C}$ for $30 \mathrm{~s}$, and then 40 cycles at $95^{\circ} \mathrm{C}$ for $15 \mathrm{~s}, 65^{\circ} \mathrm{C}$ for $15 \mathrm{~s}, 72^{\circ} \mathrm{C}$ for $30 \mathrm{~s}$, and $80^{\circ} \mathrm{C}$ for $15 \mathrm{~s}$. Fluorescence intensity was measured at $80^{\circ} \mathrm{C}$. Regarding nos $Z$ clade II (29), cycling conditions were an initial denaturation step at $95^{\circ} \mathrm{C}$ for $3 \mathrm{~min}$, followed by 40 cycles at $95^{\circ} \mathrm{C}$ for $10 \mathrm{~s}, 60^{\circ} \mathrm{C}$ for $30 \mathrm{~s}, 72^{\circ} \mathrm{C}$ for $30 \mathrm{~s}$, and $80^{\circ} \mathrm{C}$ for $30 \mathrm{~s}$. Fluorescence intensity was measured at $80^{\circ} \mathrm{C}$. Cycling conditions for AOA amo $\mathrm{A}$ (44) were an initial denaturation step at $95^{\circ} \mathrm{C}$ for $3 \mathrm{~min}$, followed by 40 cycles at $95^{\circ} \mathrm{C}$ for $10 \mathrm{~s}, 55^{\circ} \mathrm{C}$ for $30 \mathrm{~s}, 72^{\circ} \mathrm{C}$ for $30 \mathrm{~s}$, and $80^{\circ} \mathrm{C}$ for $1 \mathrm{~s}$. Fluorescence intensity was measured at $80^{\circ} \mathrm{C}$. Regarding $\mathrm{AOB}$ amo $A$ (2), cycling conditions were an initial denaturation step at $95^{\circ} \mathrm{C}$ for $3 \mathrm{~min}$, followed by 40 cycles at $95^{\circ} \mathrm{C}$ for $10 \mathrm{~s}, 57^{\circ} \mathrm{C}$ for $30 \mathrm{~s}$, $72^{\circ} \mathrm{C}$ for $30 \mathrm{~s}$, and $78^{\circ} \mathrm{C}$ for $1 \mathrm{~s}$. Fluorescence intensity was measured at $78^{\circ} \mathrm{C}$. After each run, the amplicon was visualized on an agarose gel to confirm the specific product bands of the expected size. Efficiencies for nos $Z$ clade I, clade II, AOA amoA, and AOB amoA amplification were estimated at $62,62,108$, and $82 \%$, with $R^{2}$ of $0.963,0.999,0.980$, and 0.998 , respectively.

\section{Metagenomic library construction and sequencing of nosZ genes}

The library for the shotgun metagenomic analysis for nos $Z$ genes was created with the tagmentation-based Nextera DNA Library Prep Kit (Illumina, San Diego, CA, USA) according to the manufacturer's protocol, and samples were then stored at $-20^{\circ} \mathrm{C}$. Twenty-one DNA samples were used for tagmentation: a single DNA sample from N1 due to the loss of samples, duplicate DNA samples from N3 due to the loss of samples, and triplicate DNA samples from the remaining sediment samples. The DNA quality of each library was verified by 2200 TapeStation (Agilent Technologies, Santa Clara, CA, USA), and quantified with the QubiT dsDNA HS assay kit and QubiT fluorometer (Life Technologies, Carlsbad, CA, USA). The sequencing of composite DNA samples was performed using the MiSeq V2 reagent kit $(2 \times 150 \mathrm{bp})$ on MiSeq (Illumina).

The initial quality filtering of paired-end reads was performed with MiSeq software version 2.5.0.5 (Illumina) to remove some reads with base calls below the threshold (Q30) and the trim sequences of tag and adapter. All paired-end Illumina reads were imported into CLC Genomic Workbench version 8.5.1 (CLCBio; QIAGEN, Aarhus, Denmark), and some reads that were shorter than 90 nucleotides were discarded from the libraries, resulting in $38,029,139$ read numbers (Table S1). Due to the limitation of computer memory, $30 \%$ of the N1, N2, and N3 reads were used in subsequent analyses. To detect nos $Z$ reads in the metagenomes derived from each sediment sample, publicly available NosZ amino acid references were downloaded from FunGene (http://fungene.cme.msu.edu) (18) of the Ribosomal Database Project (RDP) and the National Center for Biotechnology Information (NCBI), and then imported into the CLC Genomic Workbench. NosZ-encoding reads were identified by blastx (1) against NosZ amino acid references with an e-value threshold of $10^{-15}$. To exclude the non-NosZ amino acid sequences of uncultured bacteria with an e-value of more than $10^{-15}$ from the references, the amino acids of uncultured bacteria with an e-value of more than $10^{-15}$ in the NosZ amino acid references were aligned with archetype amino acid sequences using the CLUSTAL W program in MEGA version 7 (35). The phylogenetic tree was constructed by the maximum-likelihood method in MEGA7, resulting in 1,986 of nos Z gene reads (Table S1). Similarly, the numbers of nitric oxide reductase subunit $\mathrm{B}$ (nor $B)$ and $a m o A$ gene reads in the metagenomes were investigated as described in the supplementary information. Operational taxonomic units (OTUs) were defined as sequence groups based on the lineages constructed from the phylogenetic tree in order to compare nosZ-based diversity with a rarefaction analysis using Analytic Rarefaction 1.3 (https://strata.uga.edu/software/index.html).

\section{Statistical analysis}

A one-way analysis of variance (ANOVA) was used to analyze the significance of differences in $\mathrm{N}_{2} \mathrm{O}$ concentrations and the abundance of nos $Z$ and amoA genes before and after the incubation. Pearson's product moment correlation (PPMC) analysis was performed to assess the relationship between the increased abundance of amoA genes and elevated concentrations of $\mathrm{N}_{2} \mathrm{O}$ in the headspace of bottles after the 7-d incubation. ANOVA and PPMC analyses were performed with SPSS Statistics version 20 (IBM, Armonk, NY, USA).

\section{Nucleotide sequence accession number}

All metagenomics reported in the present study were deposited in the DNA Data Bank Japan (DDBJ) Sequence Read Archive (DRA) under accession number DRA006867. The corresponding tables between the sample names and deposit IDs of nos $Z$ gene reads on DRA006867 have been submitted to FigShare (http://dx.doi.org/ 10.6084/m9.figshare.6726428).

\section{Results}

\section{$\mathrm{N}_{2} \mathrm{O}$ emissions and sink}

$\mathrm{N}_{2} \mathrm{O}$ concentrations in the headspace after the incubation were significantly higher in non-eelgrass sediment bottles than in eelgrass sediment bottles $(P=0.010)$ (Fig. 1A), indicating that $\mathrm{N}_{2} \mathrm{O}$ emissions were higher from non-eelgrass sediments than from eelgrass sediments. Even though ammonium was supplemented to sediments, the $\mathrm{N}_{2} \mathrm{O}$ concentration in eelgrass sediment bottles $(0.022 \mu \mathrm{mol} \mathrm{L}-1)$ was similar to that in eelgrass sediment bottles without ammonium $\left(0.009 \mu \mathrm{mol} \mathrm{L}{ }^{-1}\right)$ (Fig. 1B). In contrast, the $\mathrm{N}_{2} \mathrm{O}$ concentration in the headspace of non-eelgrass sediment was 90 -fold higher than that in eelgrass sediment, implying low $\mathrm{N}_{2} \mathrm{O}$ emissions from eelgrass sediments. In addition, when a high concentration of $\mathrm{N}_{2} \mathrm{O}$ was injected into sediment bottles, $\mathrm{N}_{2} \mathrm{O}$ concentrations in the headspace after the incubation were significantly lower in eelgrass sediment bottles than in non-eelgrass sediment bottles $(P=0.011)$ (Fig. 1C), suggesting that eelgrass sediments have the capability to absorb more $\mathrm{N}_{2} \mathrm{O}$ than non-eelgrass sediments.

\section{qPCR of nosZ and amoA genes}

The abundance of nos $Z$ gene clade II in in situ sediments was significantly higher in eelgrass zone sediment Ei than in non-eelgrass zone sediment Ni $(P=0.000)$ (Fig. 2A). Similarly, after the incubation, the abundance of nos $Z$ gene clade II was higher in all types of bottles with eelgrass zone sediments E1, $\mathrm{E} 2$, and E3 than in all bottles with non-eelgrass zone sediments $\mathrm{N} 1, \mathrm{~N} 2$, and N3. Although the target lengths of PCR products for $n o s Z$ gene clade I were detected by qPCR for all samples, the abundance of nos $Z$ gene clade I was not elucidated because the fluorescent intensities of amplicons for the non-targeted region were as strong as those of the target PCR products after qPCR. 

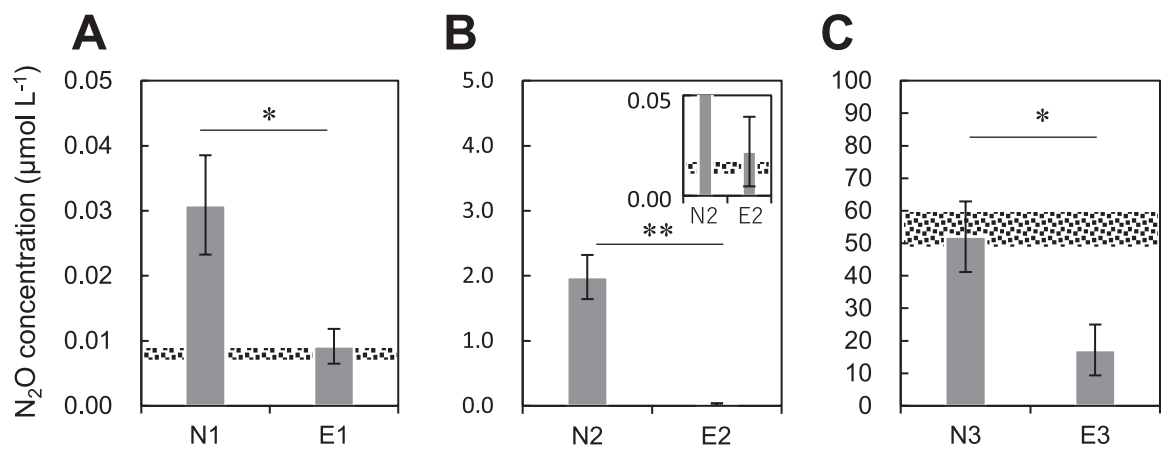

Fig. 1. Concentrations of $\mathrm{N}_{2} \mathrm{O}$ in the headspace of bottles after a 7-d incubation. (A) Sediments incubated without $\mathrm{NH}_{4} \mathrm{Cl}$ or $\mathrm{N}_{2} \mathrm{O}$ in the non-eelgrass zone $\mathrm{N} 1$ and eelgrass zone E1. (B) Sediments incubated with $\mathrm{NH}_{4} \mathrm{Cl}$ in the non-eelgrass zone $\mathrm{N} 2$ and eelgrass zone E2. (C) Sediments incubated with $\mathrm{N}_{2} \mathrm{O}$ in the non-eelgrass zone N3 and eelgrass zone E3. Error bars indicate the standard deviation ( $n=3$ biologically independent samples). * shows a significant difference $\left(*, P<0.05 *^{* *}, P<0.005\right.$ ). The gravel zone (at approximately $0.007 \mu \mathrm{mol} \mathrm{L}^{-1}$, and approximately $55 \mu \mathrm{mol} \mathrm{L}{ }^{-1}$ ) shows the initial concentrations of $\mathrm{N}_{2} \mathrm{O}$ in the headspace of bottles.
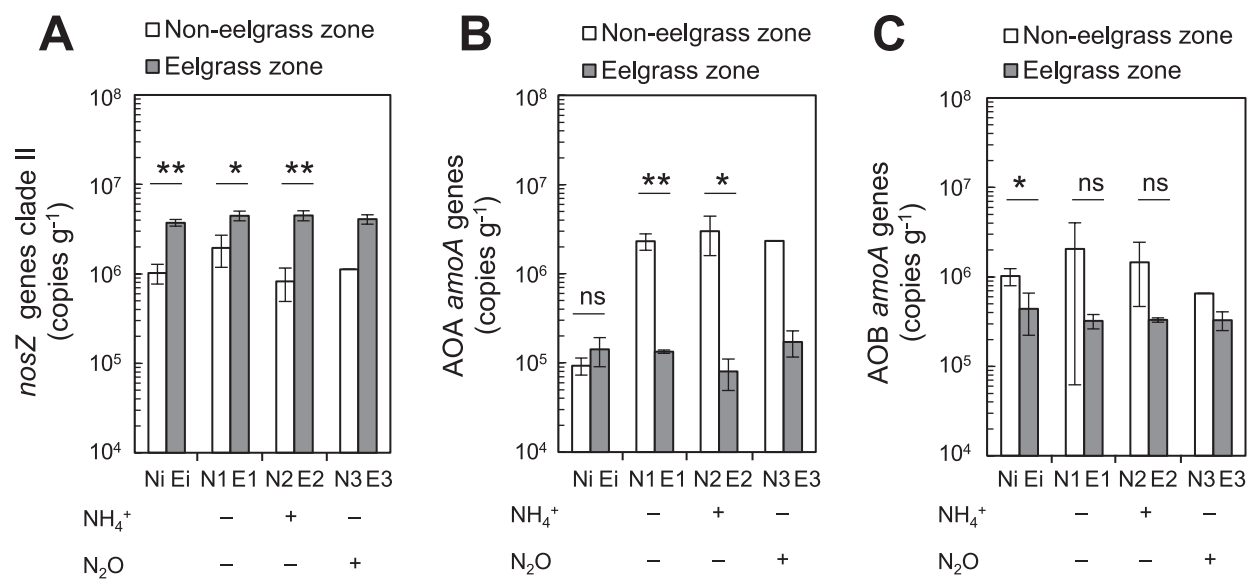

Fig. 2. Abundance of nos $Z$ gene clade II (A), AOA amoA genes (B), and AOB amoA genes $(\mathbf{C})$ in in situ sediments and bottles after day 7 of an incubation of non-eelgrass and eelgrass zones. Error bars indicate the standard deviation ( $n=3$ biologically independent samples). Only N3 is shown $(n=2) . *$ indicates a significant difference $(*, P<0.05 ; * *, P<0.005$; ns, not significant).

The abundance of the AOA amoA genes in incubated bottles with non-eelgrass zone sediments N1, N2, and N3 was approximately 10 -fold higher than that in the in situ noneelgrass zone sediment Ni (Fig. 2B). In contrast, no significant changes were observed in the abundance of AOA amoA genes between before and after the incubation among eelgrass sediment samples. In AOB amo $A$ genes, no significant differences were noted between before and after the incubation for both sediment samples (Fig. 2C). The abundance of AOB amoA genes in in situ sediments from the non-eelgrass zone (Fig. 2C, Ni) was significantly higher than that of AOA amoA genes in in situ sediments from the non-eelgrass zone (Fig. $2 \mathrm{~B}, \mathrm{Ni})(P=0.002)$. However, there was no significant change in the abundance of amoA genes between AOA (Fig. 2B, Ei) and $\mathrm{AOB}$ (Fig. $2 \mathrm{C}, \mathrm{Ei})$ in the eelgrass zone $(P=0.082)$.

\section{nosZ gene metagenome}

Shotgun metagenomic analyses based on the nos $Z$ gene revealed that nos $Z$ gene reads mainly fell into the lineages Dechloromonas-Magnetospirillum-Thiocapsa, Bacteroidetes, Myxococcales, Anaeromyxobacter-Opitutus, RhodothermusThermomicrobium, Epsilonproteobacteria, and GemmatimonadetesIgnavibacteria within nos $Z$ gene clade II, and into the lineages Alphaproteobacteria and Gammaproteobacteria within nosZ gene clade I in the non-eelgrass and/or eelgrass zones (Fig. 3A). nos Z genes within Bacteroidetes and Epsilonproteobacteria were detected as predominant members using shotgun metagenomic sequencing (Fig. 3A and B) even though they were not detected by the cloning analysis (Fig. S2). The community structural proportions of nos $Z$ gene clade II were approximately four-fold higher than those of nos $Z$ gene clade I in in situ sediments for both zones (Fig. 3B). This result was consistent with previous findings on nos $Z$ gene clade II $(51,56,70)$. Furthermore, the numbers of nos $Z$ gene reads were slightly higher than those of nor $B$ gene reads (Table S1).

In the eelgrass zone, the reads of nos $Z$ gene clade II were occupied by the dominant members of the lineages Dechloromonas-Magnetospirillum-Thiocapsa (approximately $30 \%$ ) and Bacteroidetes (approximately 30\%) in in situ and incubated sediments (Fig. 3B, Ei, E1, E2, and E3). In the lineage Dechloromonas-Magnetospirillum-Thiocapsa, the reads of the sulfur-oxidizing gammaproteobacterial nos $Z$ gene dominated (more than approximately 50\%) in in situ and incubated sediments in the eelgrass zone (Table 1, Ei, E1, E2, and E3). The majority of sulfur-oxidizing Gammaproteobacteria were related to sulfur- and sulfide-oxidizing symbionts, such as Thiolapillus brandeum isolated from a hydrothermal vent (48), 'Candidatus Thiodiazotropha endoloripes' and 'Candidatus Thiosymbion oneisti' in seagrass sediments (53), the marine bivalve mollusk Solemya velesiana gill symbiont (58), and 

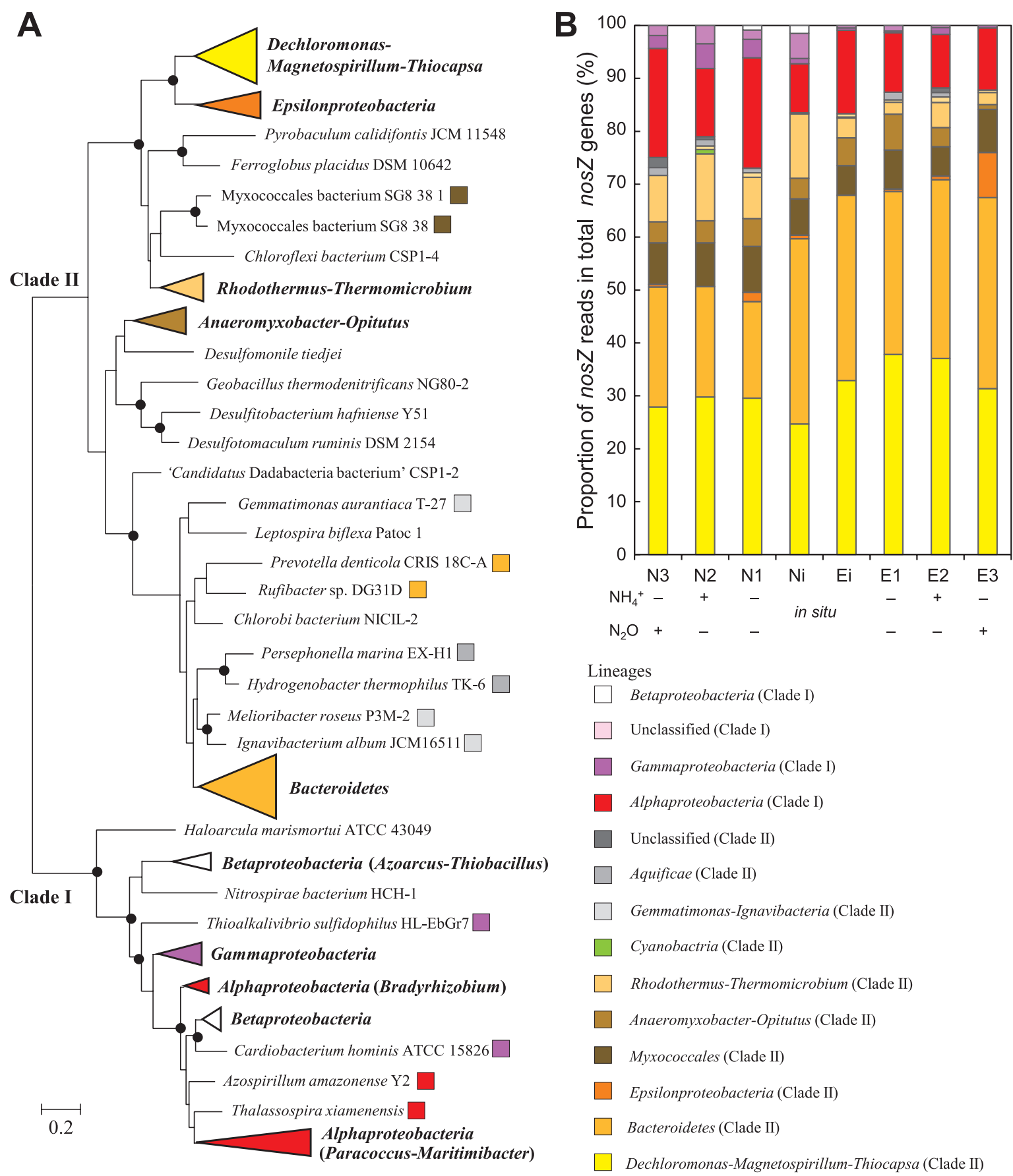

Fig. 3. Bootstrapped maximum likelihood tree (A) and average relative abundance of nos $Z$ genes (B). The tree was built from 138 archetype amino acid sequences. Branches with bootstrap support of more than $70 \%$ are revealed by closed circles. The scale bar represents an estimated sequence divergence of $20 \%$. Data represent the mean of biologically independent samples $(n=3)$. Only N1 is shown $(n=1)$, and only N3 is shown $(n=2)$.

endosymbionts of the deep-sea tubeworms Ridgeia piscesae and Tevnia jerichonana (22). Further predominant nos $Z$ gene reads were related to the giant sulfur-oxidizing bacterium 'Candidatus Thiomargarita nelsonii' (77) and anaerobic phototrophic nitrite oxidizer Thiocapsa sp. KS1 (25) in the in situ sediment of the eelgrass zone. In addition, the spiking of $\mathrm{N}_{2} \mathrm{O}$ into serum bottles (Table 1, E3 and N3) induced an increase in unclassified nos $Z$ reads related to the cytochrome $c \mathrm{~N}_{2} \mathrm{O}$ reductase ( $c$ Nos) of Epsilonproteobacteria, which dominated in the gill chamber epibiosis of the deep-sea shrimp (28).
In both zones, the lineage Bacteroidetes was dominated by nos $Z$ reads related to marine Flavobacteriia (Lutibacter, Seonamhaeicola, Maribacter, Arenibacter, Aquimarina, Cellulophaga, Bizionia, and Muricauda), such as Lutibacter profundi (78), Flavobacteriales bacterium ALC-1 (7), and Flavobacteriaceae bacterium NORP142 (74) (Table 2). In $\mathrm{N}_{2} \mathrm{O}$-supplemented sediment E3 in the eelgrass zone, in which the proportion of Epsilonproteobacteria increased (Fig. 3B), epsilonproteobacterial reads were related to $S$. gotlandica GD1 (36), Sulfurospirillum multivorans DSM 12446 (62), and Arcobacter spp. $(13,71)$. In the non-eelgrass and eelgrass 
Table 1. Average relative taxonomic distribution of nosZ gene reads within the Dechloromonas-Magnetospirillum-Thiocapsa lineage at the genus level.

\begin{tabular}{|c|c|c|c|c|c|c|c|c|c|}
\hline \multirow{2}{*}{ Genus of the lowest E-value (Accession numbers) } & \multirow{2}{*}{$\begin{array}{l}\text { Sulfur- } \\
\text { oxidizing } \\
\text { bacteria }\end{array}$} & \multicolumn{8}{|c|}{$\%^{\mathrm{a}}$} \\
\hline & & N3 & $\mathrm{N} 2$ & N1 & $\mathrm{Ni}$ & Ei & E1 & E2 & E3 \\
\hline Thiolapillus brandeum (WP_041065396) & $\mathrm{S}^{\mathrm{b}}$ & 9 & 5 & 15 & 22 & 15 & 10 & 6 & 10 \\
\hline Candidatus Thiodiazotropha spp. (WP_069019464, WP_069128191) & $\mathrm{S}$ & 9 & 16 & 6 & 8 & 14 & 10 & 12 & 13 \\
\hline Solemya velesiana gill symbiont (OOZ42363) & $\mathrm{S}$ & 9 & 12 & 15 & 2 & 10 & 8 & 6 & 4 \\
\hline Candidatus Thiosymbion oneisti (WP_089723768) & $\mathrm{S}$ & 9 & 5 & 15 & 14 & 8 & 9 & 15 & 4 \\
\hline Candidatus Thiomargarita spp. (OAD $\overline{2} 1140$, KHD07088) & $\mathrm{S}$ & 2 & 8 & 9 & 1 & 7 & 1 & 1 & 0 \\
\hline Gammaproteobacteria bacterium LUC14_002_19_P1 (OQX30387) & $\mathrm{S}$ & 9 & 8 & 6 & 4 & 5 & 2 & 0 & 4 \\
\hline Thiocapsa spp. (EGV19470, CRI65417) & $\mathrm{S}$ & 0 & 2 & 0 & 5 & 4 & 3 & 4 & 4 \\
\hline Gammaproteobacteria bacterium LUC003_P10 (OQX42463) & $\mathrm{S}$ & 9 & 6 & 6 & 1 & 4 & 4 & 6 & 10 \\
\hline endosymbiont of Ridgeia piscesae (WP_060528325, KRT60036) & $\mathrm{S}$ & 2 & 3 & 0 & 0 & 3 & 6 & 2 & 0 \\
\hline Sulfuricella denitrificans (WP_0092068577) & $\mathrm{S}$ & 0 & 0 & 0 & 0 & 1 & 6 & 1 & 0 \\
\hline Thioploca ingrica (BAP57181) & $\mathrm{S}$ & 0 & 0 & 0 & 0 & 1 & 3 & 0 & 0 \\
\hline endosymbiont of Tevnia jerichonana (vent Tica) (EGW55450) & $\mathrm{S}$ & 0 & 3 & 0 & 0 & 1 & 0 & 0 & 0 \\
\hline sulfur-oxidizing symbionts (WP_005958984) & $\mathrm{S}$ & 4 & 0 & 3 & 0 & 0 & 1 & 0 & 0 \\
\hline Sulfuritalea sp. (AIC84793) & $\mathrm{S}$ & 2 & 0 & 0 & 0 & 0 & 0 & 0 & 0 \\
\hline marine sediment metagenome (GAG54355) & $\mathrm{nd}^{\mathrm{c}}$ & 2 & 5 & 0 & 10 & 4 & 10 & 8 & 19 \\
\hline Sedimenticola spp. (WP_029133254, WP_046859760) & nd & 4 & 5 & 15 & 9 & 5 & 7 & 7 & 5 \\
\hline Gammaproteobacteria bācterium RIFOXȲD12_FULL_61_37 (OGT89854) & nd & 3 & 6 & 0 & 8 & 5 & 9 & 5 & 1 \\
\hline Magnetospira sp. (CCQ73153) & nd & 0 & 2 & 0 & 2 & 4 & 0 & 0 & 2 \\
\hline Magnetospirillum spp. (CAM74903, CDK98645, BAE51890, KIM00076, OAN53142, OAN47899) & nd & 3 & 1 & 0 & 2 & 2 & 0 & 4 & 0 \\
\hline Gammaproteobacteria bacterium HGW-Gammaproteobacteria-1 (PKM46105) & nd & 0 & 1 & 3 & 1 & 2 & 4 & 0 & 0 \\
\hline Thauera phenylacetica (ENO96869) & nd & 0 & 0 & 0 & 0 & 0 & 2 & 1 & 2 \\
\hline Candidatus Accumulibacter phosphatis (ACV36679) & nd & 0 & 0 & 0 & 0 & 0 & 0 & 2 & 0 \\
\hline Dechlorosoma aromatica (AAZ46320) & nd & 4 & 2 & 0 & 4 & 0 & 0 & 1 & 1 \\
\hline Maritimibacter sp. (WP_085526419) & nd & 0 & 0 & 3 & 0 & 0 & 0 & 8 & 2 \\
\hline unclassified bacterium & nd & 23 & 11 & 6 & 7 & 6 & 5 & 10 & 19 \\
\hline
\end{tabular}

${ }^{a}$ Data $(\%)$ represent the mean of biologically independent samples $(n=3)$. Only N1 is shown $(n=1)$, and only N3 is shown $(n=2)$.

${ }^{b} \mathrm{~S}$ represents the sulfur-oxidizing bacterium.

${ }^{\mathrm{c}}$ nd represents not determined.

zones, approximately $90 \%$ of alphaproteobacterial reads within nos $Z$ gene clade I fell into the lineage AzospirillumThalassospira-Maritimibacter-Paracoccus (Fig. 3A); however, most alphaproteobacterial reads were related to uncultured bacteria. A rarefaction analysis showed that there was no significant difference in diversity among samples (Fig. S3).

\section{Discussion}

\section{qPCR and shotgun metagenomic analyses}

The qPCR analysis based on the nos $Z$ gene revealed that the abundance of $\mathrm{N}_{2} \mathrm{O}$-reducing microbes within nos $Z$ gene clade II in in situ sediments of the eelgrass zone was 3.7-fold higher than that in the non-eelgrass zone (Fig. 2A). A previous study reported that PCR primers for nos $Z$ gene clade II are limited by PCR bias (29). Although Bacteroidetes and Epsilonproteobacteria were detected in incubated sediment E3 (sample ID: aA8) with $\mathrm{N}_{2} \mathrm{O}$ in the eelgrass zone as predominant members using shotgun metagenomic sequencing (Fig. 3B), nosZ genes related to Bacteroidetes and Epsilonproteobacteria were not detected in the same sediment E3 (sample ID: aA8) by a PCR-dependent analysis based on the nos $Z$ gene in the present study (Fig. S2). This result suggests an underestimation of the abundance of nos $Z$ gene clade II within Bacteroidetes (Flavobacteriia) and Epsilonproteobacteria. However, a shotgun metagenomic analysis based on the nos $Z$ genenotonly detected sulfide-oxidizing Gammaproteobacteria within the lineage Dechloromonas-Magnetospirillum-Thiocapsa, but also successfully identified $\mathrm{N}_{2} \mathrm{O}$-reducing microbes within Flavobacteriia and Epsilonproteobacteria from incubated sediment E3 of the eelgrass zone (Fig. 3). Therefore, a parallel analysis (qPCR and shotgun metagenomic sequencing) demonstrated that sulfide-oxidizing Gammaproteobacteria and marine Flavobacteriia were the dominant $\mathrm{N}_{2} \mathrm{O}$-reducing microbes in in situ sediments of the eelgrass zone. However, a new qPCR primer set needs to be designed to accurately evaluate the enumeration of assemblages. In addition to the contribution of $\mathrm{N}_{2} \mathrm{O}$-reducing microbes, since the numbers of $n o s Z$ reads detected were higher than those of nor $B$ reads in both in situ sediments (Table $\mathrm{S} 1$ ), the net $\mathrm{N}_{2} \mathrm{O}$ emission in in situ sediments also appears to have been suppressed by the lower abundance of microbes possessing nitric oxide reductase, which produces $\mathrm{N}_{2} \mathrm{O}$.

\section{Sulfide scavengers for $\mathrm{N}_{2} \mathrm{O}$ reduction in sulfidic sediments}

Laboratory incubation tests (Fig. 1) revealed $\mathrm{N}_{2} \mathrm{O}$ absorption by eelgrass sediments, which were black and sulfidic due to the vigorous sulfate-reducing activity of SRB in eelgrass zone (Fig. S1E). The continuous supply of hydrogen sulfide $\left(\mathrm{H}_{2} \mathrm{~S}\right)$ from the bottom sediment and dissolved dioxygen $\left(\mathrm{O}_{2}\right)$ from surface water appeared to be responsible for the growth of SOB within surface sediments in the eelgrass zone. The abundance of nos $Z$ gene clade II in in situ sediments in the eelgrass zone was approximately four-fold higher than that in in situ non-eelgrass zone sediments (Fig. 2A). However, previous studies reported that sulfide inhibits the activity of $\mathrm{N}_{2} \mathrm{O}$-reducing microbes $(42,50,68)$. Furthermore, the reduction of $\mathrm{N}_{2} \mathrm{O}$ by Anaeromyxobacter dehalogenans was inhibited in laboratory culture medium amended with $0.2 \mathrm{mM}$ sulfide (50). Sulfide concentrations may be reduced by SOB activity in seagrass sediments $(24,75)$. Therefore, SOB may act as sulfide scavengers, reducing sulfide stress for the NosZ enzyme activity of $\mathrm{N}_{2} \mathrm{O}$-reducing microbes. In addition, the 
Table 2. Average relative taxonomic distribution of nos $Z$ gene reads within the Bacteroidetes lineage at the genus level.

\begin{tabular}{|c|c|c|c|c|c|c|c|c|c|}
\hline \multirow{2}{*}{ Genus of the lowest E-value (Accession numbers) } & \multirow{2}{*}{ Class $^{\mathrm{b}}$} & \multicolumn{8}{|c|}{$\%^{\mathrm{a}}$} \\
\hline & & N3 & N2 & N1 & $\mathrm{Ni}$ & $\mathrm{Ei}$ & E1 & E2 & E3 \\
\hline unclassified Flavobacteriales (EDP71844) & F & 0 & 5 & 0 & 7 & 11 & 6 & 4 & 19 \\
\hline unclassified Flavobacteriaceae (PCI11421) & $\mathrm{F}$ & 6 & 13 & 5 & 14 & 10 & 17 & 5 & 7 \\
\hline Lutibacter spp. (WP_090224353, AMC12244, AFX81533, KUO67356) & $\mathrm{F}$ & 7 & 8 & 29 & 20 & 10 & 12 & 14 & 14 \\
\hline Seonamhaeicola spp. (WP 076698534) & $\mathrm{F}$ & 0 & 0 & 0 & 0 & 6 & 2 & 4 & 0 \\
\hline Maribacter spp. (WP 0795̄11925, EAR02377, APQ16066) & $\mathrm{F}$ & 9 & 5 & 0 & 7 & 6 & 8 & 17 & 4 \\
\hline Arenibacter spp. (WP 072764458, GAU57464) & F & 8 & 1 & 5 & 3 & 5 & 3 & 1 & 0 \\
\hline Gaetbulibacter sp. (WP_099565396) & $\mathrm{F}$ & 2 & 7 & 5 & 2 & 5 & 1 & 4 & 9 \\
\hline Aquimarina spp. (EZH71920) & $\mathrm{F}$ & 11 & 9 & 0 & 11 & 4 & 3 & 0 & 0 \\
\hline Cellulophaga spp. (WP 047414439, WP 084061063) & $\mathrm{F}$ & 5 & 1 & 10 & 3 & 4 & 3 & 7 & 2 \\
\hline Bizionia spp. (EGV4402̄4, OBX22568) & $\mathrm{F}$ & 4 & 0 & 0 & 1 & 4 & 1 & 2 & 0 \\
\hline Muricauda spp. (WP 045802108, AEM71845) & $\mathrm{F}$ & 8 & 3 & 0 & 2 & 4 & 3 & 2 & 0 \\
\hline Vitellibacter spp. (OĀD90232, KXO01187) & F & 3 & 0 & 10 & 2 & 3 & 0 & 1 & 2 \\
\hline Xanthomarina sp. (WP_007651736) & $\mathrm{F}$ & 0 & 3 & 0 & 0 & 2 & 0 & 0 & 0 \\
\hline Tenacibaculum soleae (OCK42558) & $\mathrm{F}$ & 0 & 12 & 0 & 0 & 2 & 1 & 2 & 5 \\
\hline Zobellia galactanivorans (CAZ96392) & F & 0 & 0 & 5 & 0 & 2 & 6 & 0 & 2 \\
\hline Algibacter alginicilyticus (WP_054727401) & $\mathrm{F}$ & 0 & 0 & 0 & 2 & 2 & 0 & 2 & 2 \\
\hline Myroides spp. (EKB05496, KZ̄E78434, EHO10957, GAQ13346) & $\mathrm{F}$ & 8 & 0 & 0 & 2 & 1 & 1 & 0 & 2 \\
\hline Aequorivita sublithincola (AFL79671) & $\mathrm{F}$ & 2 & 0 & 0 & 0 & 1 & 0 & 4 & 0 \\
\hline Flavobacterium enshiense (ESU23366) & $\mathrm{F}$ & 0 & 0 & 0 & 0 & 1 & 0 & 0 & 0 \\
\hline Mangrovimonas yunxiaonensis (KFB01940) & $\mathrm{F}$ & 0 & 3 & 0 & 2 & 1 & 5 & 0 & 6 \\
\hline Robiginitalea biformata (EAR16321) & $\mathrm{F}$ & 0 & 2 & 0 & 0 & 1 & 0 & 1 & 7 \\
\hline Ulvibacter litoralis (WP_093139708) & $\mathrm{F}$ & 0 & 1 & 0 & 0 & 1 & 0 & 2 & 0 \\
\hline Capnocytophaga spp. (CEN36467, EGD34772, WP 095896667) & $\mathrm{F}$ & 5 & 0 & 5 & 1 & 1 & 0 & 0 & 3 \\
\hline Psychroflexus gondwanensis (EMY80080) & $\mathrm{F}$ & 0 & 0 & 0 & 0 & 1 & 1 & 0 & 7 \\
\hline Gelidibacter algens (OBX25598) & $\mathrm{F}$ & 0 & 0 & 0 & 0 & 0 & 1 & 0 & 0 \\
\hline Gramella forsetii (CAL66385) & F & 0 & 0 & 0 & 0 & 0 & 1 & 0 & 5 \\
\hline Imtechella halotolerans (EID76831) & $\mathrm{F}$ & 3 & 1 & 0 & 1 & 0 & 5 & 0 & 0 \\
\hline Owenweeksia hongkongensis (AEV34412) & $\mathrm{F}$ & 2 & 0 & 0 & 0 & 0 & 3 & 0 & 0 \\
\hline Salegentibacter mishustinae (KRG30563) & $\mathrm{F}$ & 3 & 1 & 0 & 0 & 0 & 2 & 2 & 0 \\
\hline Zhouia amylolytica (ETN94445) & $\mathrm{F}$ & 0 & 3 & 0 & 1 & 0 & 1 & 0 & 0 \\
\hline Fulvivirga imtechensis (ELR70764) & $\mathrm{Cy}$ & 6 & 7 & 0 & 1 & 1 & 1 & 2 & 0 \\
\hline Cesiribacter andamanensis (EMR03384) & $\mathrm{Cy}$ & 0 & 0 & 5 & 0 & 0 & 0 & 0 & 0 \\
\hline Rufibacter spp. (AMM52593, AKQ46153) & $\mathrm{Cy}$ & 0 & 0 & 0 & 2 & 0 & 0 & 4 & 4 \\
\hline Runella slithyformis (AEI46569) & $\mathrm{Cy}$ & 0 & 0 & 0 & 0 & 0 & 0 & 2 & 0 \\
\hline Haliscomenobacter hydrossis (AEE53312) & $\mathrm{Sa}$ & 0 & 0 & 0 & 0 & 1 & 4 & 0 & 0 \\
\hline Phaeodactylibacter xiamenensis (KGE85855) & $\mathrm{Sa}$ & 3 & 2 & 0 & 1 & 2 & 1 & 0 & 0 \\
\hline Pedobacter glucosidilyticus (KHJ39550) & $\mathrm{Sh}$ & 0 & 0 & 0 & 1 & 0 & 0 & 0 & 0 \\
\hline Chlorobium spp. (KXB98523, KXK48569) & $\mathrm{Ch}$ & 2 & 0 & 5 & 0 & 1 & 0 & 1 & 0 \\
\hline unclassified bacterium & nd & 6 & 12 & 19 & 13 & 6 & 8 & 18 & 0 \\
\hline
\end{tabular}

${ }^{a}$ Data (\%) represent the mean of biologically independent samples $(n=3)$. Only N1 is shown $(n=1)$, and only N3 is shown $(n=2)$.

b F, Flavobacteriia; Ch, Chlorobia; Cy, Cytophagia; Sa, Saprospiria; Sh, Sphingobacteriia.

formation of $\mathrm{FeS}$ and $\mathrm{FeS}_{2}$ appeared to contribute to decreasing sulfide concentrations in eelgrass sediments.

\section{Production of $\mathrm{N}_{2} \mathrm{O}$ by nitrifiers}

The production of $\mathrm{N}_{2} \mathrm{O}$ is attributed to nitrification and denitrification in marine sediments at low oxygen concentrations (31). In the non-eelgrass zone, laboratory incubation tests indicated net $\mathrm{N}_{2} \mathrm{O}$ emission from incubated sediments (Fig. $1 \mathrm{~A}$ and $\mathrm{B})$. The abundance of $\mathrm{AOB}$ was higher than that of AOA in in situ sediments of the non-eelgrass zone (Fig. 2B and $\mathrm{C}$ ). This result supports recent findings indicating that AOB outnumbered AOA in estuary sediments influenced by human activity $(39,76,82)$. However, the abundance of AOA markedly increased after the incubation for non-eelgrass sediments only (Fig. 2B). In the non-eelgrass zone, the increased concentration of $\mathrm{N}_{2} \mathrm{O}$ in the headspace of bottles and elevated copy numbers of AOA amoA genes after the incubation in both samples without ammonium and supplemented with ammonium (Fig. S4) showed positive correlations ( $r=0.922, P<0.01$ for sediments incubated without $\mathrm{NH}_{4} \mathrm{Cl}$; $r=0.774, P=0.07$ for sediments incubated with $\mathrm{NH}_{4} \mathrm{Cl}$ ). AOA may grow under microaerobic conditions coupled with the production of $\mathrm{N}_{2} \mathrm{O}$ (55). Furthermore, dioxygen was presumed to be quickly depleted in the serum bottles. Therefore, $\mathrm{N}_{2} \mathrm{O}$ production by AOA and AOB appeared to contribute to $\mathrm{N}_{2} \mathrm{O}$ emissions in the non-eelgrass zone in addition to $\mathrm{N}_{2} \mathrm{O}$ production by denitrification. In contrast, net $\mathrm{N}_{2} \mathrm{O}$ emissions from sediments after the incubation were lower in the eelgrass zone than in the non-eelgrass zone (Fig. 1A and B). Furthermore, no significant increase in AOA or AOB amoA genes occurred after the incubation in eelgrass sediment bottles (Fig. 2B and C). Therefore, the production of $\mathrm{N}_{2} \mathrm{O}$ by nitrification appeared to be inhibited in incubated bottles from the eelgrass zone.

\section{Heterotrophic and autotrophic $\mathrm{N}_{2} \mathrm{O}$ reduction}

nosZ genes within Flavobacteriia were detected from in situ sediments in the non-eelgrass and eelgrass zones (Fig. 3B). Flavobacteriia are one of the most abundant populations in aquatic environments (32) including seagrass sediments $(12,17,73)$. They are proficient at degrading high-molecularweight organic matter (32). Recent metagenomic analyses using next-generation sequencers demonstrated that some Flavobacteriia possess nos $Z$ genes, suggesting their capacity to reduce $\mathrm{N}_{2} \mathrm{O}(7,74,78)$. Heterotrophic $\mathrm{N}_{2} \mathrm{O}$ reduction is 
preferable to gain energy, such as $\mathrm{N}_{2} \mathrm{O}$ reduction using acetate as the electron donor: $2 \mathrm{~N}_{2} \mathrm{O}+1.5 \mathrm{C}_{2} \mathrm{H}_{3} \mathrm{O}_{2}{ }^{-} \rightarrow 2 \mathrm{~N}_{2}+\mathrm{HCO}_{3}{ }^{-}+1.5 \mathrm{H}^{+}$ ( $\Delta G^{\circ}=600 \mathrm{~kJ}$ per reaction) (37). $\mathrm{N}_{2} \mathrm{O}$ reduction may be one of the preferential reactions to yield energy for Flavobacteriia in the absence of dioxygen as an electron acceptor in sulfidic sediments.

Sulfur-oxidizing $\mathrm{N}_{2} \mathrm{O}$-reducing microbes within nos $\mathrm{Z}$ gene clade II were one of the highest populations in sulfidic sediments of the eelgrass zone (Fig. 3B and Table 1). Autotrophic denitrification coupled with sulfide oxidation, $2 \mathrm{NO}_{3}{ }^{-}+5 \mathrm{HS}^{-}+7 \mathrm{H}^{+} \rightarrow \mathrm{N}_{2}+5 \mathrm{~S}^{\circ}+6 \mathrm{H}_{2} \mathrm{O}\left(\Delta G^{\circ}=-1,260 \mathrm{~kJ}\right.$ per reaction), is a favorable reaction for chemolithotrophs (37). The sulfur-oxidizing gammaproteobacterium $T$. brandeum (48) and sulfur-oxidizing epsilonproteobacterium $S$. gotlandica (36) have the ability to grow autotrophically with nitrate as an electron acceptor. Since nos $Z$ genes related to T. brandeum and $S$. gotlandica were predominantly detected from sediments in the eelgrass zone in the present study, autotrophic denitrification by SOB also appears to be responsible for the $\mathrm{N}_{2} \mathrm{O}$ sink in sediments in the eelgrass zone. The highest rate of complete denitrification was reported at $40 \mathrm{~m}$ within the peak of $\mathrm{H}_{2} \mathrm{~S}$ in the marine oxygen minimum zone off Peru, suggesting that autotrophic SOB reduced $\mathrm{N}_{2} \mathrm{O}$ with $\mathrm{H}_{2} \mathrm{~S}$ in the oxygen minimum zone (63).

A previous study reported that the $\mathrm{N}_{2} \mathrm{O}$ consumption rates of the heterotrophic $\mathrm{N}_{2} \mathrm{O}$ reducers, $P$. stutzeri, Shewanella loihica, Dechloromonas aromatica, and A. dehalogenans, were $4.16,0.446,0.461$, and $0.0171 \mu \mathrm{mol} \mathrm{min}^{-1} \mathrm{mg}$ biomass $^{-1}$, respectively (81). Similarly, the $\mathrm{N}_{2} \mathrm{O}$ consumption rate of the autotrophic $\mathrm{N}_{2} \mathrm{O}$ reducer Thiohalorhabdus denitrificans was 180-300 nmol min ${ }^{-1} \mathrm{mg}$ protein ${ }^{-1}$ (69). Although no significant differences have been reported in $\mathrm{N}_{2} \mathrm{O}$ reduction rates between heterotrophic and autotrophic $\mathrm{N}_{2} \mathrm{O}$ reducers, the substrate affinity of clade II $\operatorname{nos} Z \mathrm{~N}_{2} \mathrm{O}$ reducers for $\mathrm{N}_{2} \mathrm{O}$ is generally higher than that of clade I $\operatorname{nos} Z \mathrm{~N}_{2} \mathrm{O}$ reducers $(6,59,81)$. The $K_{m}$ value of soil Flavobacteriia sp. for $\mathrm{N}_{2} \mathrm{O}$ was $0.5 \mu \mathrm{M}(6)$. Thus, the predominance of clade II $\operatorname{nos} Z \mathrm{~N}_{2} \mathrm{O}$ reducers in eelgrass sediments appears to be due to differences in affinity for $\mathrm{N}_{2} \mathrm{O}$ between clade I and clade II $\operatorname{nos} Z \mathrm{~N}_{2} \mathrm{O}$ reducers. Since the surface of eelgrass zone sediments was covered with dead leaves (Fig. S1D and E), the heterotrophic denitrifier Flavobacteriia may play an important role in the $\mathrm{N}_{2} \mathrm{O}$ sink with organic matter as an electron donor. However, soil Flavobacteriia sp. have been shown to produce $\mathrm{N}_{2} \mathrm{O}$ as oxygen tension increases (6). The Flavobacteriia nos $Z$ phylotype was detected as the predominant member at the $\mathrm{N}_{2} \mathrm{O}$ peak within marine oxygen-deficient zones in the Eastern Tropical North Pacific (ETNP) (21). Further studies are needed to clarify whether heterotrophic and autotrophic $\mathrm{N}_{2} \mathrm{O}$ reducers contribute to the $\mathrm{N}_{2} \mathrm{O}$ sink in in situ eelgrass sediments.

\section{Conclusions}

A shotgun metagenomic analysis based on the nos $Z$ gene coupled with quantitative and physiological experiments suggested an $\mathrm{N}_{2} \mathrm{O}$ sink due to the $\mathrm{N}_{2} \mathrm{O}$-reducing microbiome in sediments of the eelgrass zone. Seagrass meadows are widely distributed along coastal environments worldwide (66). Therefore, $\mathrm{N}_{2} \mathrm{O}$-reducing microbiomes in seagrass meadows play an important role in the global nitrogen cycle, and have the potential to mitigate $\mathrm{N}_{2} \mathrm{O}$ from coastal environments worldwide. Future studies on the vertical distribution of $\mathrm{N}_{2} \mathrm{O}-$ reducing microbiomes coupled with the vertical dynamics of dissolved $\mathrm{N}_{2} \mathrm{O}$, sulfide $\left(\mathrm{HS}^{-}\right), \mathrm{NO}_{3}{ }^{-}, \mathrm{O}_{2}$, ferrous $\left(\mathrm{Fe}^{2+}\right)$, the oxidation-reduction potential, and stable isotopic composition of $\mathrm{NO}_{3}{ }^{-}$(49) in sediments, and also on sulfur-oxidizing symbionts involved in $\mathrm{N}_{2} \mathrm{O}$ reduction are needed in order to provide a comprehensive understanding of the role of seagrass sediment microbiomes as an $\mathrm{N}_{2} \mathrm{O}$ sink. Since rapid precipitation is expected to increase, the effects of $\mathrm{NO}_{3}{ }^{-}$outflow by nitrogen fertilizers on the production of $\mathrm{N}_{2} \mathrm{O}$ in eelgrass zone sediments warrant further study.

\section{Acknowledgements}

We are grateful to the crew of the Etopirika for their technical expertise. We wish to thank Daisuke Imaizumi, Asuka Yamada, Ken Jinguji, Rino Tomizawa, Yuki Miyamoto, Midori Morikawa, Kengo Sudo, Sanae Taguchi, Naoya Ishikawa, Takumi Nomura, and Hayato Kokubu for their support with the chemical and microbiological analyses, Kazuhiro Umezawa for his support with the field work, the staff of the General Research Institute for their support with sequencing at Nihon University, and Shujiro Okuda for his discussions and technical advice on bioinformatics. We thank the three anonymous reviewers for their helpful comments. This work was supported in part by grants from the Joint Research Program of the Institute of Low Temperature Science, Hokkaido University to T.N.

\section{References}

1. Altschul, S.F., T.L. Madden, A.A. Schäffer, J. Zhang, Z. Zhang, W. Miller, and D.J. Lipman. 1997. Gapped BLAST and PSI-BLAST: a new generation of protein database search programs. Nucleic Acids Res. 25:3389-3402.

2. Ando, Y., T. Nakagawa, R. Takahashi, K. Yoshihara, and T. Tokuyama. 2009. Seasonal changes in abundance of ammonia-oxidizing archaea and ammonia-oxidizing bacteria and their nitrification in sand of an eelgrass zone. Microbes Environ. 24:21-27.

3. Arfken, A., B. Song, J.S. Bowman, and M. Piehler. 2017. Denitrification potential of the eastern oyster microbiome using a 16S rRNA gene based metabolic inference approach. PLoS One 12:e185071.

4. Babbin, A.R., D. Bianchi, A. Jayakumar, and B.B. Ward. 2015. Rapid nitrous oxide cycling in the suboxic ocean. Science 348:1127-1129.

5. Beller, H.R., T.E. Letain, A. Chakicherla, S.R. Kane, T.C. Legler, and M.A. Coleman. 2006. Whole-genome transcriptional analysis of chemolithoautotrophic thiosulfate oxidation by Thiobacillus denitrificans under aerobic versus denitrifying conditions. J. Bacteriol. 188:70057015.

6. Betlach, M.R., and J.M. Tiedje. 1981. Kinetic explanation for accumulation of nitrite, nitric oxide, and nitrous oxide during bacterial denitrification. Appl. Environ. Microbiol. 42:1074-1084.

7. Bonilla-Rosso, G., L. Eguiarte, and V. Souza. 2014. Functional and taxonomic diversity of the nitrogen cycling guild in the Sargasso Sea metagenomes. Theory, Methods and Applications, p.153-173. In D. Marco (ed.), Metagenomics of the Microbial Nitrogen Cycle. Caister Academic Press, Norfolk.

8. Caffrey, J.M., and W.M. Kemp. 1990. Nitrogen cycling in sediments with estuarine populations of Potamogeton perfoliatus and Zostera marina. Mar. Ecol. Prog. Ser. 66:147-160.

9. Calleja, M.L., N. Marbà, and C.M. Duarte. 2007. The relationship between seagrass (Posidonia oceanica) decline and sulfide porewater concentration in carbonate sediments. Estuarine, Coastal Shelf Sci. 73:583-588.

10. Cifuentes, A., J. Antón, S. Benlloch, A. Donnelly, R.A. Herbert, and F. Rodríguez-Valera. 2000. Prokaryotic diversity in Zostera noltiicolonized marine sediments. Appl. Environ. Microbiol. 66:1715-1719.

11. Coyle, C.L., W.G. Zumft, P.M.H. Kroneck, H. Körner, and W. Jakob. 1985. Nitrous oxide reductase from denitrifying Pseudomonas perfectomarina. Purification and properties of a novel multicopper enzyme. Eur. J. Biochem. 153:459-467. 
12. Cúcio, C., A.H. Engelen, R. Costa, and G. Muyzer. 2016. Rhizosphere microbiomes of european seagrasses are selected by the plant, but are not species specific. Front. Microbiol. 7:440.

13. Diéguez, A.L., S. Balboa, T. Magnesen, and J.L. Romalde. 2017. Arcobacter lekithochrous sp. nov., isolated from a molluscan hatchery. Int. J. Syst. Evol. Microbiol. 67:1327-1332.

14. Domeignoz-Horta, L.A., M. Putz, A. Spor, D. Bru, M.C. Breuil, S. Hallin, and L. Philippot. 2016. Non-denitrifying nitrous oxide-reducing bacteria-an effective $\mathrm{N}_{2} \mathrm{O}$ sink in soil. Soil Biol. Biochem. 103:376-379.

15. Duan, Y.-F., X.-W. Kong, A. Schramm, R. Labouriau, J. Eriksen, and S.O. Petersen. 2017. Microbial $\mathrm{N}$ transformations and $\mathrm{N}_{2} \mathrm{O}$ emission after simulated grassland cultivation: effects of the nitrification inhibitor 3,4-dimethylpyrazole phosphate (DMPP). Appl. Environ. Microbiol. 83:e02019-16.

16. Duffy, J.E., P.L. Reynolds, C. Boström, et al. 2015. Biodiversity mediates top-down control in eelgrass ecosystems: a global comparativeexperimental approach. Ecol. Lett. 18:696-705.

17. Fahimipour, A.K., M.R. Kardish, J.M. Lang, J.L. Green, J.A. Eisen, and J.J. Stachowicz. 2017. Global-scale structure of the eelgrass microbiome. Appl. Environ. Microbiol. 83:e03391-16.

18. Fish, J.A., B. Chai, Q. Wang, Y. Sun, C.T. Brown, J.M. Tiedje, and J.R. Cole. 2013. FunGene: the functional gene pipeline and repository. Front. Microbiol. 4:291.

19. Flood, B.E., D.S. Jones, and J.V. Bailey. 2015. Complete genome sequence of Sedimenticola thiotaurini strain SIPG1, a polyphosphateand polyhydroxyalkanoate-accumulating sulfur-oxidizing gammaproteobacterium isolated from salt marsh sediments. Genome Announc. 3:e00671-15.

20. Foster, S.Q., and R.W. Fulweiler. 2016. Sediment nitrous oxide fluxes are dominated by uptake in a temperate estuary. Front. Mar. Sci. 3:40

21. Fuchsman, C.A., A.H. Devol, J.K. Saunders, C. McKay, and G. Rocap. 2017. Niche partitioning of the N cycling microbial community of an offshore oxygen deficient zone. Front. Microbiol. 8:2384.

22. Gardebrecht, A., S. Markert, S.M. Sievert, et al. 2012. Physiological homogeneity among the endosymbionts of Riftia pachyptila and Tevnia jerichonana revealed by proteogenomics. ISME J. 6:766-776.

23. Hallam, S.J., T.J. Mincer, C. Schleper, C.M. Preston, K. Roberts, P.M. Richardson, and E.F. DeLong. 2006. Pathways of carbon assimilation and ammonia oxidation suggested by environmental genomic analyses of marine Crenarchaeota. PLoS Biol. 4:520-536.

24. Hasler-Sheetal, H., and M. Holmer. 2015. Sulfide intrusion and detoxification in the seagrass Zostera marina. PLoS One 10:e129136.

25. Hemp, J., S. Lücker, J. Schott, L.A. Pace, J.E. Johnson, B. Schink, H. Daims, and W.W. Fischer. 2016. Genomics of a phototrophic nitrite oxidizer: insights into the evolution of photosynthesis and nitrification. ISME J. 10:2669-2678.

26. Henry, S., D. Bru, B. Stres, S. Hallet, and L. Philippot. 2006. Quantitative detection of the nos $Z$ gene, encoding nitrous oxide reductase, and comparison of the abundances of $16 \mathrm{~S}$ rRNA, $\operatorname{nar} G$, nirK, and nos Z genes in soils. Appl. Environ. Microbiol. 72:5181-5189.

27. Herbert, R.A. 1999. Nitrogen cycling in coastal marine ecosystems. FEMS Microbiol. Rev. 23:563-590.

28. Jan, C., J.M. Petersen, J. Werner, et al. 2014. The gill chamber epibiosis of deep-sea shrimp Rimicaris exoculata: an in-depth metagenomic investigation and discovery of Zetaproteobacteria. Environ. Microbiol. $16: 2723-2738$

29. Jones, C.M., D.R. Graf, D. Bru, L. Philippot, and S. Hallin. 2013. The unaccounted yet abundant nitrous oxide-reducing microbial community: a potential nitrous oxide sink. ISME J. 7:417-426.

30. Jones, C.M., A. Spor, F.P. Brennan, M.-C. Breuil, D. Bru, P. Lemanceau, B. Griffiths, S. Hallin, and L. Philippot. 2014. Recently identified microbial guild mediates soil $\mathrm{N}_{2} \mathrm{O}$ sink capacity. Nat. Clim. Change 4:801-805.

31. Jørgensen, K.S., H.B. Jensen, and J. Sørensen. 1984. Nitrous oxide production from nitrification and denitrification in marine sediment at low oxygen concentrations. Can. J. Microbiol. 30:1073-1078.

32. Kirchman, D.L. 2002. The ecology of Cytophaga-Flavobacteria in aquatic environments. FEMS Microbiol. Ecol. 39:91-100.

33. Kojima, H., and M. Fukui. 2011. Sulfuritalea hydrogenivorans gen. nov., sp. nov., a facultative autotroph isolated from a freshwater lake. Int. J. Syst. Evol. Microbiol. 61:1651-1655.

34. Körner, H., and W.G. Zumft. 1989. Expression of denitrification enzymes in response to the dissolved oxygen level and respiratory substrate in continuous culture of Paeudomonas stutzeri. Appl. Environ. Microbiol. 55:1670-1676.
35. Kumar, S., G. Stecher, and K. Tamura. 2016. MEGA7: molecular evolutionary genetics analysis version 7.0 for bigger datasets. Mol. Biol. Evol. 33:1870-1874.

36. Labrenz, M., J. Grote, K. Mammitzsch, H.T.S. Boschker, M. Laue, G. Jost, S. Glaubitz, and K. Jürgens. 2013. Sulfurimonas gotlandica sp. nov., a chemoautotrophic and psychrotolerant epsilonproteobacterium isolated from a pelagic redoxcline, and an emended description of the genus Sulfurimonas. Int. J. Syst. Evol. Microbiol. 63:4141-4148.

37. Lam, P., and M.M.M. Kuypers. 2011. Microbial nitrogen cycling processes in oxygen minimum zone. Ann. Rev. Mar. Sci. 3:317-345.

38. Lamb, J.B., J.A.J.M. van de Water, D.G. Bourne, C. Altier, M.Y. Hein, E.A. Fiorenza, N. Abu, J. Jompa, and C.D. Harvell. 2017. Seagrass ecosystems reduce exposure to bacterial pathogens of humans, fishes, and invertebrates. Science 355:731-733.

39. Li, J., D.B. Nedwell, J. Beddow, A.J. Dumbrell, B.A. McKew, E.L. Thorpe, and C. Whitby. 2015. amoA Gene abundances and nitrification potential rates suggest that benthic ammonia-oxidizing bacteria and not archaea dominate $\mathrm{N}$ cycling in the Colne Estuary, United Kingdom. Appl. Environ. Microbiol. 81:159-165.

40. Löscher, C.R., A. Kock, M. Könneke, J. LaRoche, H.W. Bange, and R.A. Schmitz. 2012. Production of oceanic nitrous oxide by ammoniaoxidizing archaea. Biogeosciences 9:2419-2429.

41. Maher, D.T., J.Z. Sippo, D.R. Tait, C. Holloway, and I.R Santos. 2016. Pristine mangrove creek waters are a sink of nitrous oxide. Sci. Rep. 6:25701.

42. Manconi, I., P. van der Maas, and P. Lens. 2006. Effect of copper dosing on sulfide inhibited reduction of nitric and nitrous oxide. Nitric Oxide 15:400-407.

43. Masuda, Y., H. Itoh, Y. Shiratori, K. Isobe, S. Otsuka, and K. Senoo. 2017. Predominant but previously-overlooked prokaryotic drivers of reductive nitrogen transformation in paddy soils, revealed by metatranscriptomics. Microbes Environ. 32:180-183.

44. Meinhardt, K.A., A. Bertagnolli, M.W. Pannu, S.E. Strand, S.L. Brown, and D.A. Stahl. 2015. Evaluation of revised polymerase chain reaction primers for more inclusive quantification of ammonia-oxidizing archaea and bacteria. Environ. Microbiol. Rep. 7:354-363.

45. Montzka, S.A., E.J. Dlugokencky, and J.H. Butler. 2011. Non- $\mathrm{CO}_{2}$ greenhouse gases and climate change. Nature 476:43-50.

46. Murray, R.H., D.V. Erler, and B.D. Eyre. 2015. Nitrous oxide fluxes in estuarine environments: response to global change. Glob. Chang. Biol. 21:3219-3245.

47. Nishio, T., I. Koike, and A. Hattori. 1983. Estimates of denitrification and nitrification in coastal and estuarine sediments. Appl. Environ. Microbiol. 45:444-450.

48. Nunoura, T., Y. Takaki, H. Kazama, J. Kakuta, S. Shimamura, H. Makita, M. Hirai, M. Miyazaki, and K. Takai. 2014. Physiological and genomic features of a novel sulfur-oxidizing gammaproteobacterium belonging to a previously uncultivated symbiotic lineage isolated from a hydrothermal vent. PLoS One 9:e104959.

49. Nunoura, T., M. Nishizawa, M. Hirai, et al. 2018. Microbial diversity in sediments from the bottom of the Challenger Deep, the Mariana Trench. Microbes Environ. 33:186-194.

50. Onley, J.R., S. Ahsan, R.A. Sanford, and F.E. Löffler. 2018. Denitrification by Anaeromyxobacter dehalogenans, a common soil bacterium lacking the nitrite reductase genes nirS and nirK. Appl. Environ. Microbiol. 84:e01985-17.

51. Orellana, L.H., L.M. Rodriguez-R, S. Higgins, J.C. Chee-Sanford, R.A. Sanford, K.M. Ritalahti, and K.T. Konstantinidis. 2014. Detecting nitrous oxide reductase (nosZ) genes in soil metagenomes: method development and implications for the nitrogen cycle. mBio 5:e0119314.

52. Park, D., H. Kim, and S. Yoon. 2017. Nitrous oxide reduction by an obligate aerobic bacterium, Gemmatimonas aurantiaca strain T-27. Appl. Environ. Microbiol. 83:e00502-17.

53. Petersen, J.M., A. Kemper, H. Gruber-Vodicka, et al. 2016. Chemosynthetic symbionts of marine invertebrate animals are capable of nitrogen fixation. Nat. Microbiol. 2:16195.

54. Portmann, R.W., J.S. Daniel, and A.R. Ravishankara. 2012. Stratospheric ozone depletion due to nitrous oxide: influences of other gases. Phil. Trans. R. Soc. B 367:1256-1264

55. Qin, W., K.A. Meinhardt, J.W. Moffett, A.H. Devol, E.V. Armbrust, A.E. Ingalls, and D.A. Stahl. 2017. Influence of oxygen availability on the activities of ammonia-oxidizing archaea. Environ. Microbiol. Rep. 9:250-256. 
56. Rasigraf, O., J. Schmitt, M.S.M. Jetten, and C. Lüke. 2017. Metagenomic potential for and diversity of $\mathrm{N}$-cycle driving microorganisms in the Bothnian Sea sediment. MicrobiologyOpen 6:e00475.

57. Rotthauwe, J.-H., K.-P. Witzel, and W. Liesack. 1997. The ammonia monooxygenase structural gene $a m o A$ as a functional marker: molecular fine-scale analysis of natural ammonia-oxidizing populations. Appl. Environ. Microbiol. 63:4704-4712.

58. Russell, S.L., R.B. Corbett-Detig, and C.M. Cavanaugh. 2017. Mixed transmission modes and dynamic genome evolution in an obligate animal-bacterial symbiosis. ISME J. 11:1359-1371.

59. Sameshima-Saito, R., K. Chiba, J. Hirayama, M. Itakura, H. Mitsui, S. Eda, and K. Minamisawa. 2006. Symbiotic Bradyrhizobium japonicum reduces $\mathrm{N}_{2} \mathrm{O}$ surrounding the soybean root system via nitrous oxide reductase. Appl. Environ. Microbiol. 72:2526-2532.

60. Sanford, R.A., D.D. Wagner, Q. Wu, et al. 2012. Unexpected nondenitrifier nitrous oxide reductase gene diversity and abundance in soils. Proc. Natl. Acad. Sci. U.S.A. 109:19709-19714.

61. Santoro, A.E., C. Buchwald, M.R. McIlvin, and K.L. Casciotti. 2011. Isotopic signature of $\mathrm{N}_{2} \mathrm{O}$ produced by marine ammonia-oxidizing archaea. Science 333:1282-1285.

62. Scholz-Muramatsu, H., A. Neumann, M. Meßmer, E. Moore, and G. Diekert. 1995. Isolation and characterization of Dehalospirillum multivorans gen. nov., sp. nov., a tetrachloroethene-utilizing, strictly anaerobic bacterium. Arch. Microbiol. 163:48-56.

63. Schunck, H., G. Lavik, D.K. Desai, et al. 2013. Giant hydrogen sulfide plume in the oxygen minimum zone off Peru supports chemolithoautotrophy. PLoS One 8:e68661.

64. Shao, M.-F., T. Zhang, and H. Fang. 2010. Sulfur-deriving autotrophic denitrification: diversity, biochemistry, and engineering applications. Appl. Microbiol. Biotechnol. 88:1027-1024.

65. Shapleigh, J.P. 2006. The denitrifying prokaryotes, p. 769-792. In M. Dworkin, S. Falkow, E. Rosenberg, K.-H. Schleifer, and E. Stackebrandt (ed.), The Prokaryotes: A Handbook on the Biology of Bacteria, 3rd ed., vol. 2: Ecophysiology and Biochemistry, Springer, New York.

66. Short, F., T. Carruthers, W. Dennison, and M. Waycott. 2007. Global seagrass distribution and diversity: A bioregional model. J. Exp. Mar. Biol. Ecol. 350:3-20.

67. Sievert, S.M., K.M. Scott, M.G. Klotz, et al. 2008. Genome of the epsilonproteobacterial chemolithoautotroph Sulfurimonas denitrificans. Appl. Environ. Microbiol. 74:1145-1156.

68. Sørensen, J., J.M. Tiedje, and R.B. Firestone. 1980. Inhibition by sulfide of nitric and nitrous oxide reduction by denitrifying Pseudomonas fluorescens. Appl. Environ. Microbiol. 39:105-108.

69. Sorokin, D.Y., T.P. Tourova, E.A. Galinski, G. Muyzer, and J.G. Kuenen. 2008. Thiohalorhabdus denitrificans gen. nov., sp. nov., an extremely halophilic, sulfur-oxidizing, deep-lineage gammaproteobacterium from hypersaline habitats. Int. J. Syst. Evol. Microbiol. 58:2890-2897.

70. Sun, X., A. Jayakumar, and B.B. Ward. 2017. Community composition of nitrous oxide consuming bacteria in the oxygen minimum zone of the eastern tropical south pacific. Front. Microbiol. 8:1183.
71. Tanaka, R., I. Cleenwerck, Y. Mizutani, S. Iehata, P. Bossier, and P. Vandamme. 2017. Arcobacter haliotis sp. nov., isolated from abalone species Haliotis gigantea. Int. J. Syst. Evol. Microbiol. 67:3050-3056.

72. Thomson, A.J., G. Giannopoulos, J. Pretty, E.M. Baggs, and D.J. Richardson. 2012. Biological sources and sinks of nitrous oxide and strategies to mitigate emissions. Philos. Trans. R. Soc., B 367:11571168.

73. Trevathan-Tackett, S.M., J.R. Seymour, D.A. Nielsen, et al. 2017. Sediment anoxia limits microbial-driven seagrass carbon remineralization under warming conditions. FEMS Microbiol. Ecol. 93:fix033.

74. Tully, B.J., C.G. Wheat, B.T. Glazer, and J.A. Huber. 2018. A dynamic microbial community with high functional redundancy inhabits the cold, oxic subseafloor aquifer. ISME J. 12:1-16.

75. Van der Heide, T., L.L. Govers, J. de Fouw, et al. 2012. A three-stage symbiosis forms the foundation of seagrass ecosystems. Science 336:1432-1434.

76. Wankel, S.D., A.C. Mosier, C.M. Hansel, A. Paytan, and C.A. Francis. 2011. Spatial variability in nitrification rates and ammoniaoxidizing microbial communities in the agriculturally impacted Elkhorn Slough estuary, California. Appl. Environ. Microbiol. 77:269-280.

77. Winkel, M., V. Salmon-Carvalho, T. Woyke, M. Richter, H.N. Schulz-Vogt, B.E. Flood, J.V. Bailey, and M. Mußmann. 2016. Single-cell sequencing of Thiomargarita reveals genomic flexibility for adaptation to dynamic redox conditions. Front. Microbiol. 7:964.

78. Wissuwa, J., S.L.M. Bauer, I.H. Steen, and R. Stokke. 2017. Complete genome sequence of Lutibacter profundi $\mathrm{LP}^{\mathrm{T}}$ isolated from an Arctic deep-sea hydrothermal vent system. Stand. Genomic Sci. 12:5.

79. Wittorf, L., G. Bonilla-Rosso, C.M. Jones, O. Bäckman, S. Hulth, and S. Hallin. 2016. Habitat partitioning of marine benthic denitrifier communities in response to oxygen availability. Environ. Microbiol. Rep. 8:486-492.

80. Yamada, K., K. Takahashi, C. Vallet, S. Taguchi, and T. Toda. 2007. Distribution, life history, and production of three species of Neomysis in Akkeshi-ko estuary, northern Japan. Mar. Biol. (Heidelberg, Ger.) 150:905-917.

81. Yoon, S., S. Nissen, D. Park, R.A. Sanford, and F.E. Löffler. 2016 Nitrous oxide reduction kinetics distinguish bacteria harboring clade I nosZ from those harboring clade II nosZ. Appl. Environ. Microbiol. 82:3793-3800.

82. Zheng, Y., L. Hou, S. Newell, M. Liu, J. Zhou, H. Zhao, L. You, and X. Cheng. 2014. Community dynamics and activity of ammoniaoxidizing prokaryotes in intertidal sediments of the Yangtze Estuary. Appl. Environ. Microbiol. 80:408-419.

83. Zhu, X., M. Burger, T.A. Doane, and W.R. Horwath. 2013. Ammonia oxidation pathways and nitrifier denitrification are significant sources of $\mathrm{N}_{2} \mathrm{O}$ and $\mathrm{NO}$ under low oxygen availability. Proc. Natl. Acad. Sci. U.S.A. 110:6328-6333.

84. Zumft, W.G., and P.M.H. Kroneck. 2007. Respiratory transformation of nitrous oxide $\left(\mathrm{N}_{2} \mathrm{O}\right)$ to dinitrogen by Bacteria and Archaea. Adv. Microb. Physiol. 52:107-227. 